\title{
The efficacy of anti-PD-1/PD-L1 therapy and its comparison with EGFR-TKIs for advanced non-small-cell lung cancer
}

\author{
Zhixin Sheng ${ }^{1}$, Xu Zhu ${ }^{1}$, Yanhua Sun ${ }^{1}$ and Yanxia Zhang ${ }^{2}$ \\ ${ }^{1}$ Department of Hematology, Weifang People's Hospital, Weifang, China \\ ${ }^{2}$ Department of Oncology, Linyi People's Hospital, Linyi, China \\ Correspondence to: Yanxia Zhang, email: shengzhixin5569@126.com \\ Keywords: anti-PD-1/PD-L1 therapy, atezolizumab, pembrolizumab, nivolumab, NSCLC
}

Received: February 24, $2017 \quad$ Accepted: May 12, $2017 \quad$ Published: June 08, 2017

Copyright: Sheng et al. This is an open-access article distributed under the terms of the Creative Commons Attribution License 3.0 (CC BY 3.0), which permits unrestricted use, distribution, and reproduction in any medium, provided the original author and source are credited.

\section{ABSTRACT}

Purpose: To better understand the efficacy and safety of anti-PD-1/PD-L1 therapy (atezolizumab, pembrolizumab, nivolumab) in patients with previously treated advanced non-small-cell lung cancer (NSCLC).

Methods: The Cochrane Controlled Trial Register, Embase, Medline, and the Science Citation Index were searched for prospective published reports of atezolizumab, pembrolizumab, nivolumab in previously treated patients with advanced NSCLC.

Results: Finally, we identified 14 prospective published reports including four trials of atezolizumab covering 542 subjects, three trials of pembrolizumab covering 1566 subjects, seven trials of nivolumab covering 1678 subjects. When compared to docetaxel, anti-PD-1/PD-L1 therapy could significantly improve overall survival (hazard ratio $[H R] 0.67, P<0.001$ ) and progression-free survival (HR 0.83, $P=0.002$ ) for previously treated patients with advanced NSCLC. Anti-PD-1/PD-L1 therapy produced an overall response rate of $19 \%$ in the 2374 evaluable patients. When using docetaxel as the common comparator, indirect comparison of anti-PD-1/PDL1 therapy versus EGFR-TKIs showed progression-free survival benefit (HR 0.62, $P<0.001)$ and overall survival benefit $(H R 0.60, P<0.001)$ for those patients with EGFR wild-type. Meanwhile, for those EGFR mutant patients, indirect comparison indicated that anti-PD-1/PD-L1 therapy was inferior to EGFR-TKIs therapy in terms of progression-free survival (HR 3.20, P<0.001), but no survival difference (HR 1.30, $P=0.18$ ).

Conclusion: Anti-PD-1/PD-L1 therapy could produce progression-free survival and overall survival improvement over docetaxel for patients with previously treated NSCLC. For EGFR wild-type patients, anti-PD-1/PD-L1 therapy seemed to prolong progression-free survival and overall survival when compared to EGFR-TKIs. Meanwhile, for these EGFR mutant patients, anti-PD-1/PD-L1 therapy was inferior to EGFR-TKIs therapy in terms of progression-free survival.

\section{INTRODUCTION}

The interaction of programmed death 1 (PD-1) with the non-small-cell lung cancer (NSCLC) expressed ligands programmed death-ligand 1 (PD-L1) and PD$\mathrm{L} 2$ could downregulate $\mathrm{T}$ cell activity and promote tumor immune escape [1-4]. Recently, anti-PD-1/PD-
L1 therapy (atezolizumab, pembrolizumab, nivolumab) which could disrupt PD-1/PD-L1-mediated signaling and restore antitumor immunity had been reported to be a good treatment option for advanced NSCLC [5-18]. However, whether anti-PD-1/PD-L1 therapy could provide progression free survival (PFS) improvement still remained undefined for previously treated patients with 
advanced NSCLC. PFS improvement was only shown in two of the four trials [5-8]. With these results variable, the meta-analysis tried to evaluate the activity and safety of anti-PD-1/PD-L1 therapy in previously treated advanced NSCLC. The primary endpoints were PFS, overall survival (OS), overall response rate (ORR) derived from anti-PD-1/PD-L1 therapy.

Epidermal growth factor receptor tyrosine kinase inhibitors (EGFR-TKIs) such as gefitinib and erlotinib have been used as suggested for heavily pretreated molecularly selected patients with NSCLC [19-22]. Both anti-PD-1/PD-L1 therapy and EGFR-TKIs are considered as vital breakthroughs in the management of advanced NSCLC and are credited for changing this once dismal history of previously treated advanced NSCLC. However, direct head-to-head comparison between EGFR-TKIs and anti-PD-1/PD-L1 therapy is lacking. When a direct comparison is not available, another way to assess the relative activity of competing regimens is to undertake an indirect comparison. Thus, we applied an adjusted indirect comparison analysis to evaluate the relative activity of anti-PD-1/PD-L1 therapy versus EGFR-TKIs for previously treated patients with advanced NSCLC using common comparator.

\section{RESULTS}

\section{Characteristics of the published reports}

Finally, we identified 14 prospective published reports including four trials of atezolizumab covering 542 subjects, three trials of pembrolizumab covering 1566 subjects, seven trials of nivolumab covering 1678 subjects. And, four trials of EGFR-TKIs covering 2475 subjects were also included for indirect comparison [5-22]. All RCTs reported intention-to-treat analyses, description of dropouts, and generation of allocation sequence, however none of them was blind [5-8, 19-22]. Study flow diagram was indicated in Figure 1. Table 1 summarized the characteristics of 18 identified clinical reports.

\section{Comparison of anti-PD-1/PD-L1 therapy vs. docetaxel}

In the total population, the pooled analysis indicated that anti-PD-1/PD-L1 therapy consistently reduced the risk of death by $33 \%$ over docetaxel (hazard ratio [HR] $0.67, \mathrm{P}<0.001)$, and prolonged the PFS by $17 \%(\mathrm{HR}$ $0.83, \mathrm{P}<0.001$ ) (Figure 2). The values for heterogeneity

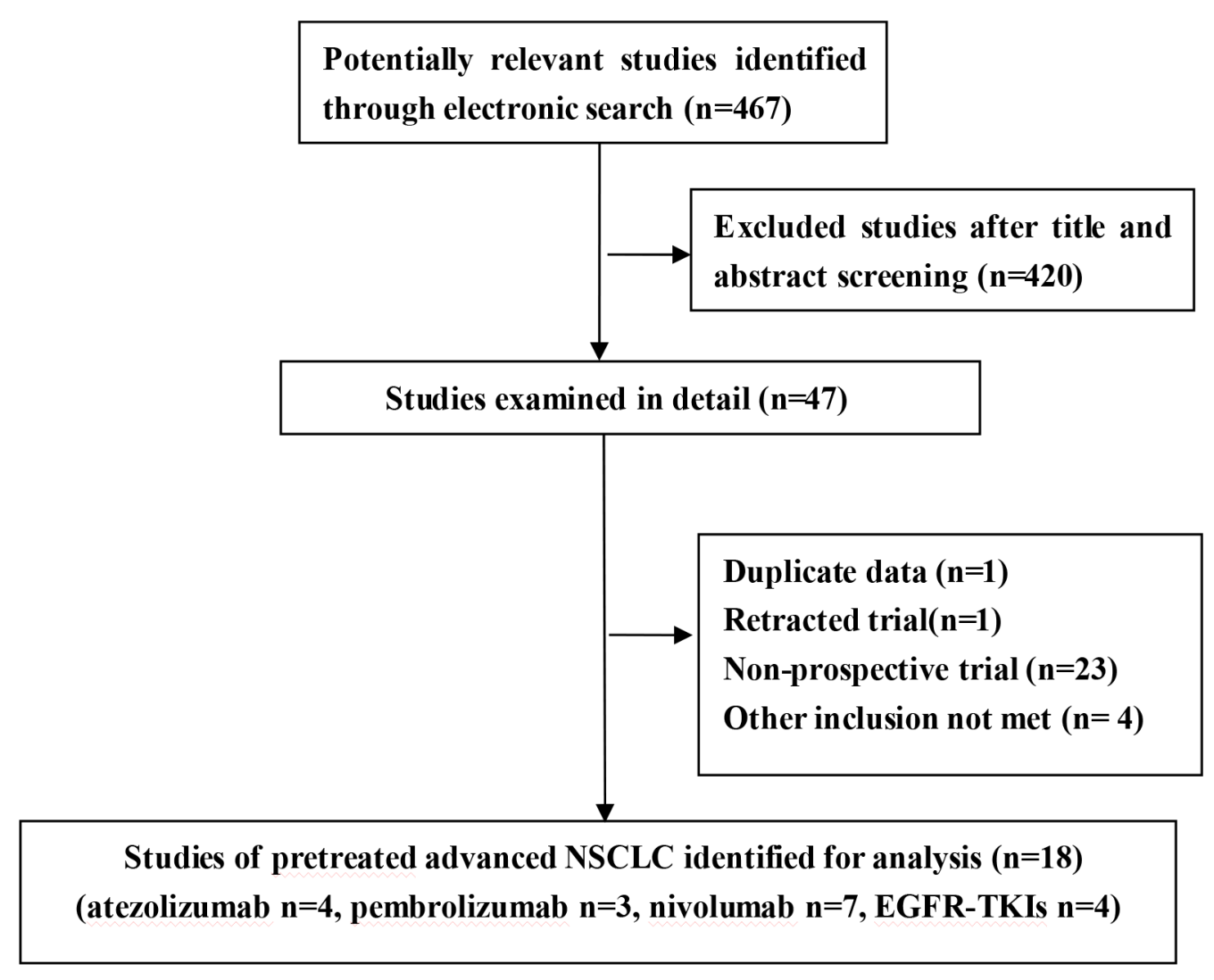

Figure 1: Study flow diagram. 
Table 1: Main characteristics of the studies included in the meta-analysis

\begin{tabular}{|c|c|c|c|c|c|c|c|}
\hline \multirow{2}{*}{ Study name (year) } & \multirow{2}{*}{$\mathbf{N}$} & \multicolumn{2}{|c|}{$\mathbf{n}$} & \multirow{2}{*}{ Therapy regimen } & \multirow{2}{*}{$\begin{array}{c}\text { Age } \\
\text { median }\end{array}$} & \multirow{2}{*}{$\begin{array}{c}\text { Smoker/ } \\
\text { non-smoker }\end{array}$} & \multirow{2}{*}{ Trial type } \\
\hline & & EGFR - & EGFR $^{+}$ & & & & \\
\hline \multicolumn{8}{|c|}{ Anti-PD-1/PD-L1 therapy Trials } \\
\hline \multirow[t]{2}{*}{ Fehrenbacher 2016 [5] } & 287 & - & - & Ate $1200 \mathrm{mg}, \mathrm{q} 3 \mathrm{w}$ & 62 & $117 / 27$ & $\mathrm{RCT}$ \\
\hline & & & & Doc $75 \mathrm{mg} / \mathrm{m} 2, \mathrm{q} 3 \mathrm{w}$ & 62 & $114 / 29$ & \\
\hline \multirow[t]{2}{*}{ Herbst 2016 [6] } & 1033 & 875 & 86 & $\begin{array}{l}\text { Pem } 2 \mathrm{mg} / \mathrm{kg} \text { or } \\
10 \mathrm{mg} / \mathrm{kg}, \mathrm{q} 3 \mathrm{w}\end{array}$ & 63 & $564 / 123$ & $\mathrm{RCT}$ \\
\hline & & & & Doc $75 \mathrm{mg} / \mathrm{m} 2, \mathrm{q} 3 \mathrm{w}$ & 62 & $269 / 67$ & \\
\hline \multirow[t]{2}{*}{ Borghaei 2015 [7] } & 582 & 340 & 82 & Niv $3 \mathrm{mg} / \mathrm{kg}, \mathrm{q} 2 \mathrm{w}$ & 61 & $231 / 58$ & $\mathrm{RCT}$ \\
\hline & & & & Doc $75 \mathrm{mg} / \mathrm{m} 2, \mathrm{q} 3 \mathrm{w}$ & 64 & $227 / 60$ & \\
\hline \multirow[t]{2}{*}{ Brahmer 2015 [8] } & 272 & - & - & Niv 3 mg/kg, q2w & 62 & $121 / 10$ & $\mathrm{RCT}$ \\
\hline & & & & Doc $75 \mathrm{mg} / \mathrm{m} 2, \mathrm{q} 3 \mathrm{w}$ & 64 & $129 / 7$ & \\
\hline Herbst 2014 [9] & 53 & - & - & $\begin{array}{c}\text { Ate } 0.3,1,3,10 \text { and } \\
20 \mathrm{mg} / \mathrm{kg}, \mathrm{q} 3 \mathrm{w} \\
10,15 \text { or } 20 \mathrm{mg} / \mathrm{kg} \\
\text { q3 } 3\end{array}$ & 60 & $68 / 17$ & $\begin{array}{l}\text { Single- } \\
\text { arm }\end{array}$ \\
\hline Spigel 2015 [10] & 114 & - & - & Ate $1200 \mathrm{mg}$, q3w & - & - & $\begin{array}{l}\text { Single- } \\
\text { arm }\end{array}$ \\
\hline Horn 2015 [11] & 88 & - & - & Ate $20 \mathrm{mg} / \mathrm{kg} \mathrm{q} 3 \mathrm{w}$ & - & - & $\begin{array}{l}\text { Single- } \\
\text { arm }\end{array}$ \\
\hline Garon 2015 [12] & 495 & - & - & $\begin{array}{l}\text { Pem } 2 \mathrm{mg} / \mathrm{kg} \text { or } \\
10 \mathrm{mg} / \mathrm{kg}, \mathrm{q} 3 \mathrm{w} ; \\
10 \mathrm{mg} / \mathrm{kg}, \mathrm{q} 2 \mathrm{w}\end{array}$ & 64 & $369 / 126$ & $\begin{array}{l}\text { Single- } \\
\text { arm }\end{array}$ \\
\hline Gandhi 2014 [13] & 38 & - & - & Pem 10mg/kg, q3w & - & - & $\begin{array}{l}\text { Single- } \\
\text { arm }\end{array}$ \\
\hline Gettinger 2015 [14] & 129 & - & - & $\begin{array}{c}\text { Niv 1-, 3-, or } 10-\mathrm{mg} / \\
\text { kg, q2w }\end{array}$ & 65 & - & $\begin{array}{l}\text { Single- } \\
\text { arm }\end{array}$ \\
\hline Rizvi 2015 [15] & 117 & - & - & Niv $3 \mathrm{mg} / \mathrm{k}$, q2w & 65 & $108 / 9$ & $\begin{array}{l}\text { Single- } \\
\text { arm }\end{array}$ \\
\hline Brahmer 2012 [16] & 49 & - & - & $\begin{array}{c}\text { Niv } 0.3,1,3 \text {, and } 10 \\
\mathrm{mg} / \mathrm{kg}, \mathrm{q} 2 \mathrm{w}\end{array}$ & 65 & - & $\begin{array}{l}\text { Single- } \\
\text { arm }\end{array}$ \\
\hline Topalian 2012 [17] & 122 & - & - & $\begin{array}{c}\text { Niv } 1,3 \text {, and } 10 \mathrm{mg} / \\
\mathrm{kg}, \mathrm{q} 2 \mathrm{w}\end{array}$ & 65 & - & $\begin{array}{l}\text { Single- } \\
\text { arm }\end{array}$ \\
\hline Gettinger 2014 [18] & 20 & - & - & Niv $3 \mathrm{mg} / \mathrm{k}$, q2w & - & - & $\begin{array}{l}\text { Single- } \\
\text { arm }\end{array}$ \\
\hline \multicolumn{8}{|l|}{ EGFR-TKIs Trials } \\
\hline \multirow[t]{2}{*}{ Maruyama 2008 [19] } & 489 & 26 & 31 & Gef $250 \mathrm{mg} / \mathrm{d}$ & - & $174 / 71$ & $\mathrm{RCT}$ \\
\hline & & & & Docl $60 \mathrm{mg} / \mathrm{m} 2, \mathrm{q} 3 \mathrm{w}$ & - & $157 / 87$ & \\
\hline \multirow[t]{2}{*}{ Douillard 2010 [20] } & 1466 & 253 & 44 & Gef $250 \mathrm{mg} / \mathrm{d}$ & 61 & $585 / 148$ & $\mathrm{RCT}$ \\
\hline & & & & Doc $75 \mathrm{mg} / \mathrm{m} 2, \mathrm{q} 3 \mathrm{w}$ & 60 & $583 / 150$ & \\
\hline Garassino 2013 [21] & 219 & 219 & 0 & $\operatorname{Erl} 150 \mathrm{mg} / \mathrm{d}$ & 66 & $90 / 19$ & $\mathrm{RCT}$ \\
\hline
\end{tabular}




\begin{tabular}{|c|c|c|c|c|c|c|c|}
\hline \multirow{2}{*}{ Study name (year) } & \multirow{2}{*}{$\mathbf{N}$} & \multicolumn{2}{|c|}{$\mathbf{n}$} & \multirow{2}{*}{ Therapy regimen } & \multirow{2}{*}{$\begin{array}{c}\text { Age } \\
\text { median }\end{array}$} & \multirow{2}{*}{$\begin{array}{c}\text { Smoker/ } \\
\text { non-smoker }\end{array}$} & \multirow{2}{*}{ Trial type } \\
\hline & & EGFR - & EGFR $^{+}$ & & & & \\
\hline \multirow{3}{*}{ Kawaguchi 2014 [22] } & \multirow{3}{*}{301} & \multirow{3}{*}{199} & \multirow{3}{*}{56} & Doc $75 \mathrm{mg} / \mathrm{m} 2, \mathrm{q} 3 \mathrm{w}$ & 67 & $80 / 30$ & \multirow{3}{*}{$\mathrm{RCT}$} \\
\hline & & & & Erl $150 \mathrm{mg} / \mathrm{d}$ & 68 & $111 / 39$ & \\
\hline & & & & Doc $60 \mathrm{mg} / \mathrm{m} 2, \mathrm{q} 3 \mathrm{w}$ & 67 & $114 / 37$ & \\
\hline
\end{tabular}

$\mathrm{EGFR}^{+}$: presence of epidermal growth factor receptor mutation; EGFR ${ }^{-}$: absence of epidermal growth factor receptor mutation; Ate: atezolizumab; Pem: pembrolizumab; Doc: docetaxel; Gef: gefitinib; Erl: erlotinib; -: not available; N: the total number of patients; $\mathrm{n}$ : the number of patients with known EGFR status; RCT: randomised controlled trials.
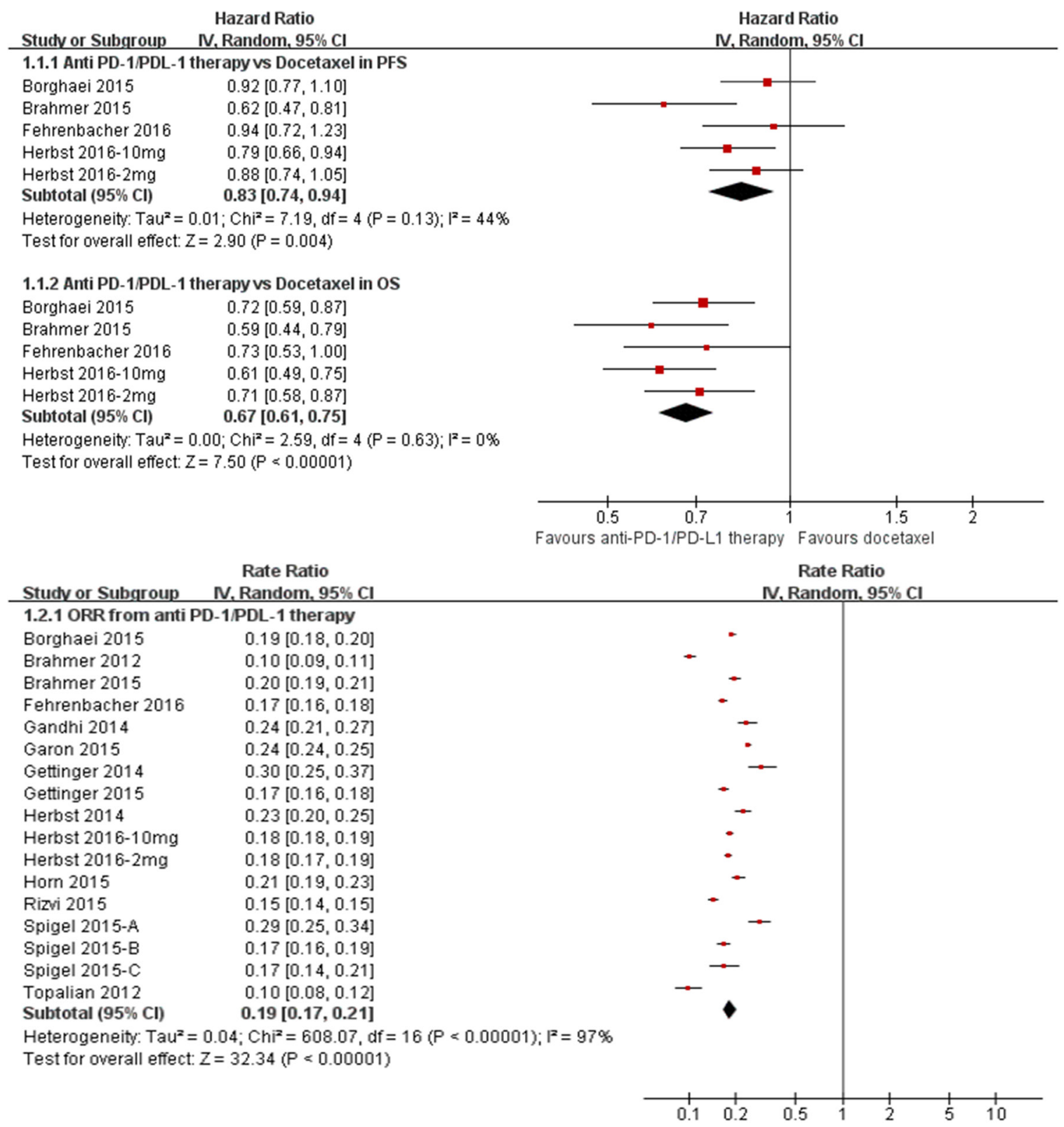

Figure 2: Meta-analysis of the treatment effects of anti-PD-1/PD-L1 therapy in patients with advanced non-small cell lung cancer. (1.1) anti-PD-1/PD-L1 therapy vs. Docetaxel in progression free survival (PFS) and overall survival (OS);(1.2) overall response rate (ORR) from anti-PD-1/PD-L1 therapy. CI: 95 \% confidence interval; Random: random-effects model. 
tests across these trials were $I^{2}=0 \%, \mathrm{P}=1.00$ for $\mathrm{OS}$ analysis; $I^{2}=44 \%, \mathrm{P}=0.13$ for PFS analysis. The HRs in this analysis of OS favored anti-PD-1/PD-L1 therapy across most prespecified subpopulation; the exceptions were the subpopulation who lived in the rest-of-theworld geographic region, those with age more than 75 years, those with central nervous system metastases, those who had never smoked, and those with EGFR mutation(Figure 3). And, similar results was shown in PFS analysis(Figure 3). And, anti-PD-1/PD-L1 therapy resulted in an impressive ORR of 19\%(Figure 2). No significant publication bias was found in the ORR analysis $(\mathrm{P}=$ $0.582)$. The value for heterogeneity test across these trials was $I^{2}=97 \%, \mathrm{P}<0.001$ for ORR analysis.

Subgroup analyses by the tumor PD-L1 expression level indicated that anti-PD-1/PD-L1 therapy could significantly prolong both PFS and OS in patients of high PD-L1 expressions, but not in those with low expressions, regardless of PD-L1 expression level of $1 \%, 5 \%$, and $10 \%$ (Figure 4). Furthermore, this analysis declared statistically
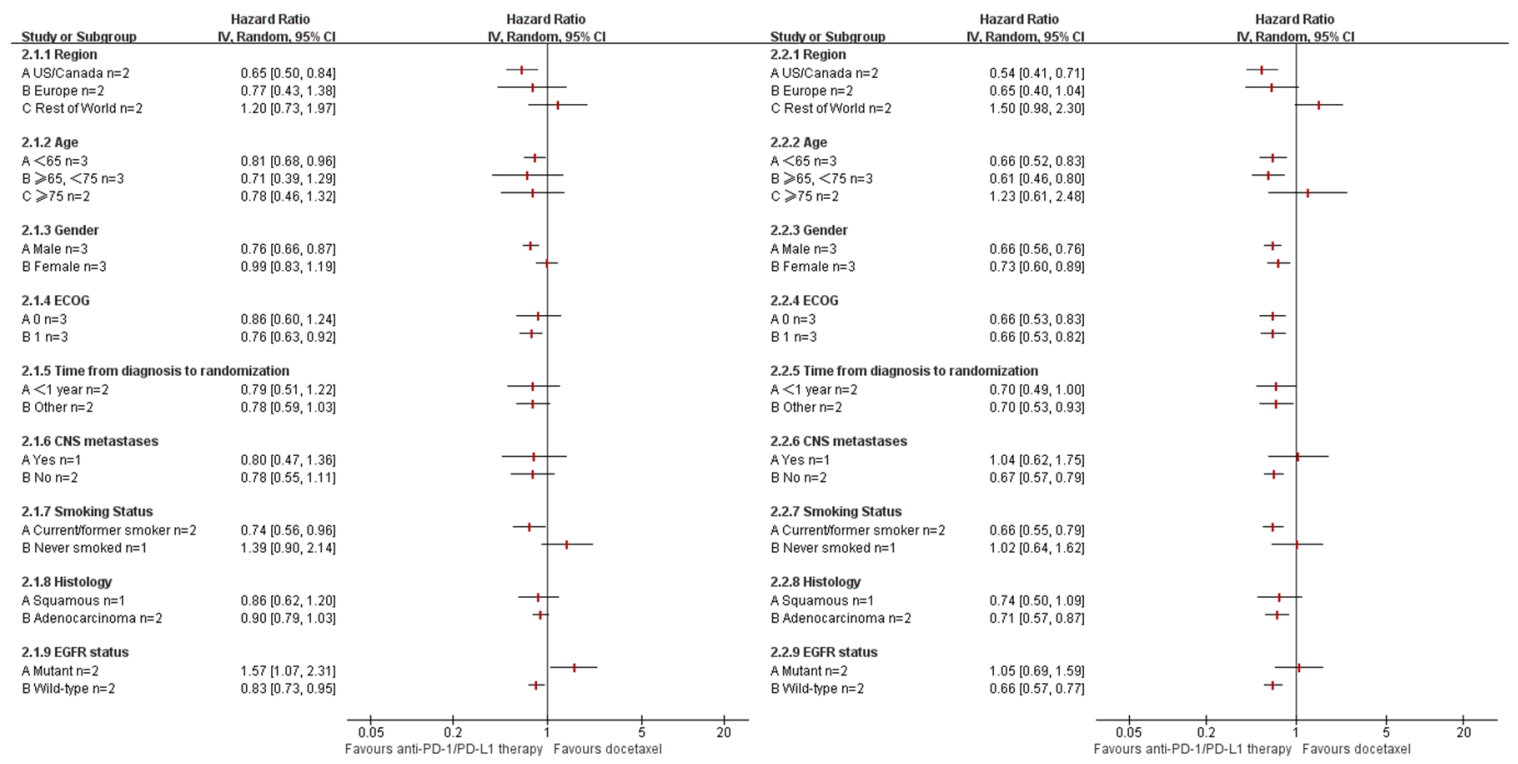

Figure 3: Subgroup Meta-analysis of progression free survival (PFS) and overall survival (OS). (2.1) anti-PD-1/PDL1 therapy vs. Docetaxel in PFS; (2.2) anti-PD-1/PD-L1 therapy vs. Docetaxel in OS. ECOG: Eastern Cooperative Oncology Group performance status; CI: $95 \%$ confidence interval; Random: random-effects model.
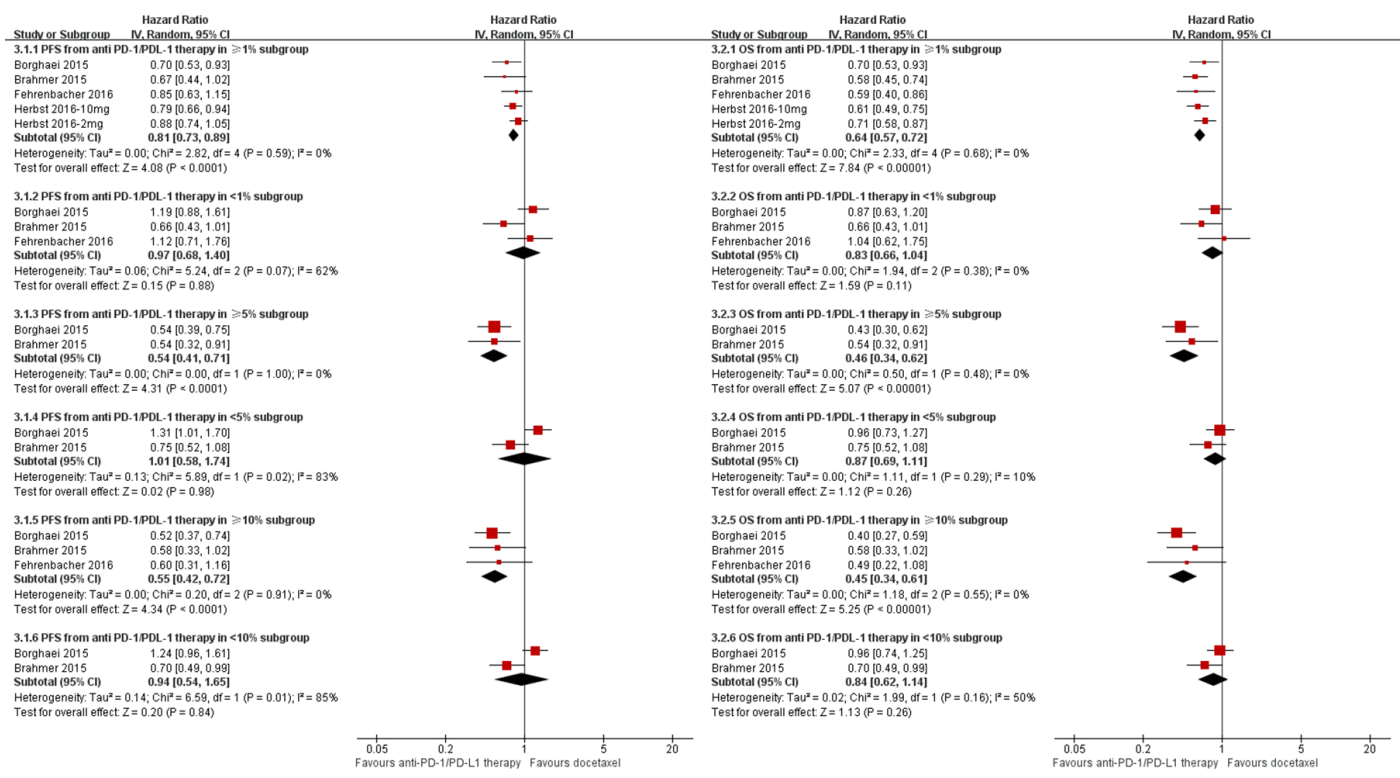

Figure 4: Meta-analysis of progression free survival (PFS) and overall survival (OS) by PD-L1 Expression Level. (3.1) anti-PD-1/PD-L1 therapy vs. Docetaxel in PFS; (3.2) anti-PD-1/PD-L1 therapy vs. Docetaxel in OS. CI: 95 \% confidence interval; Random: random-effects model. 
significant difference between PD-L1 expression level of $\geq 5 \%$ and $<5 \%(\mathrm{P}=0.0008)$, between $\mathrm{PD}-\mathrm{L} 1$ expression level of $\geq 10 \%$ and $<10 \%(\mathrm{P}=0.005)$ in $\mathrm{OS}$ analysis. And, PFS analysis indicated a marginal difference between PD$\mathrm{L} 1$ expression level of $\geq 5 \%$ and $<5 \%(\mathrm{P}=0.05)$.

Generally, the rates of adverse events (AEs) of anti-PD-1/PD-L1 therapy seemed to be lower than that of docetaxel (Figure 5).

\section{Indirect comparison of anti-PD-1/PD-L1 therapy vs. EGFR-TKIs via common comparator of docetaxel}

When using docetaxel as common comparator, our indirect comparison indicated that anti-PD-1/PD-L1 could reduce the progression of risk by $38 \%$ (HR 0.62 ,
$\mathrm{P}<0.001$ ), and prolonged OS by $40 \%$ (HR $0.60, \mathrm{P}<0.001)$ for those EGFR wild-type patients(Figure 6). This finding has special meaning, because a larger number of patients with advanced NSCLC are EGFR wild-type. Meanwhile, for those EGFR mutant patients, indirect comparison indicated that anti-PD-1/PD-L1 therapy was inferior to EGFR-TKIs therapy in terms of PFS (HR 3.20, $\mathrm{P}<0.001$ ), but no survival difference between them (HR 1.30, $\mathrm{P}=0.18$ ) (Figure 6).

\section{DISCUSSION}

In this pooled analysis, an impressive ORR of $19 \%$ derived from anti-PD-1/PD-L1 therapy compared favorably to the ORRs of $7 \%$ to $9 \%$ from current secondline therapies for advanced NSCLC [24-26]. Furthermore,

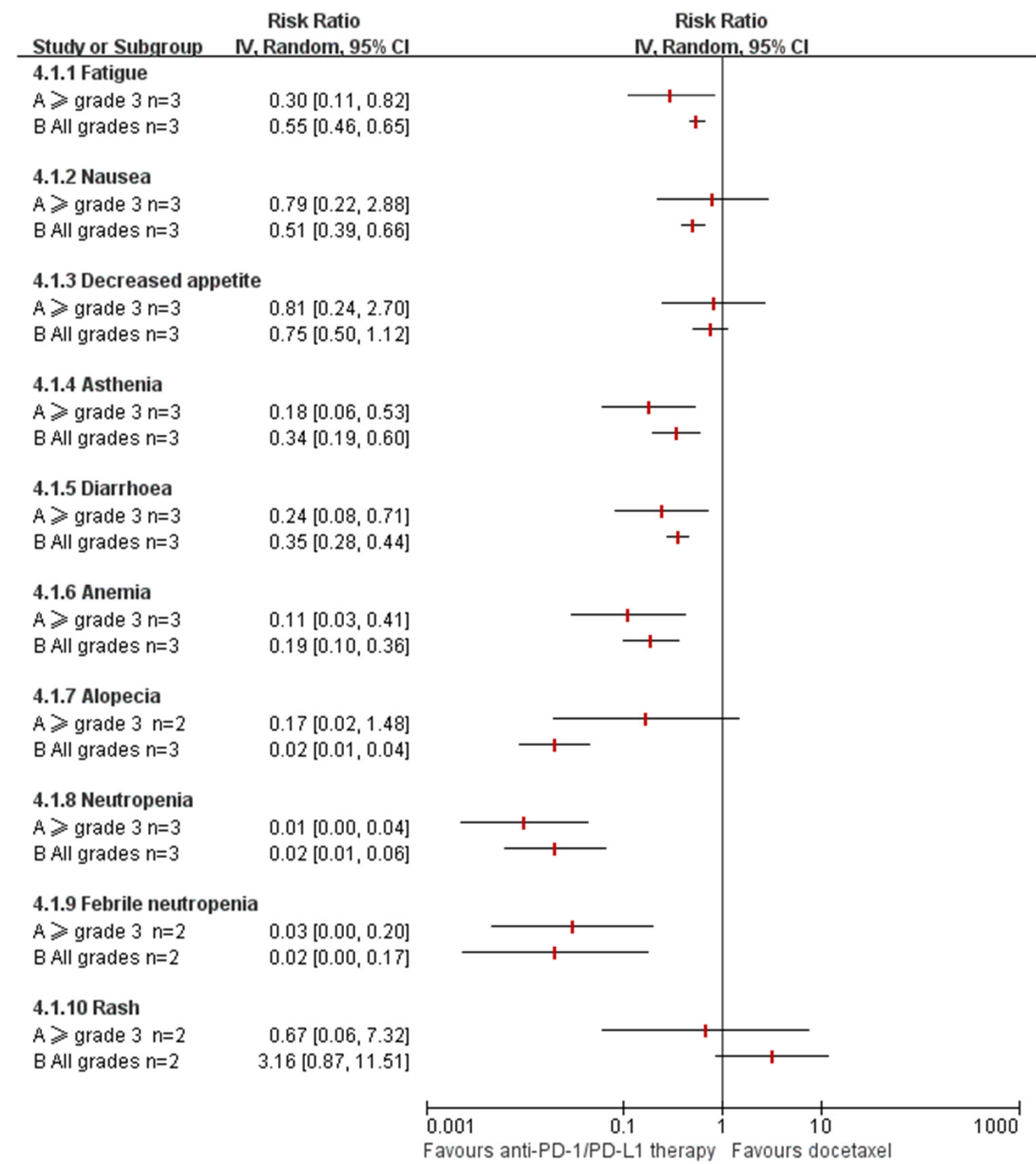

Figure 5: Meta-analysis of adverse events (AEs) of anti-PD-1/PD-L1 therapy vs. Docetaxel in previously treated patients with advanced non-small cell lung cancer. $n$ : the number of included trials for analysis; CI: $95 \%$ confidence interval; Random: random-effects model. 
anti-PD-1/PD-L1 therapy clearly benefited patients over docetaxel concerning PFS and OS. These data contribute to the increasing evidence that supports PD-1 pathway inhibition in advanced NSCLC. Anti-PD-1/PD-L1 therapy related with fewer treatment-related adverse events than was docetaxel. Unlike chemotherapy, immune checkpoint inhibitors by blocking the PD-1 inhibitory receptor tried to restore antitumor immunity. So anti-PD-1/PD-L1 therapy added to chemotherapy might be a good option for such patients. Ongoing trials are assessing anti-PD-1/PD-L1 therapy as adjuvant therapy (PEARLS, ClinicalTrials. gov numberNCT02504372). These trials were enrolling patients using different biomarker cutpoints, and which cutpoint could best predict the activity of anti-PD-1/PD-L1 therapy still remains undefined. Furthermore, this analysis indicated statistically significant difference between PDL1 expression level of $\geq 5 \%$ and $<5 \%(\mathrm{P}=0.0008)$, between PD-L1 expression level of $\geq 10 \%$ and $<10 \%(\mathrm{P}=0.005)$ in OS analysis. And, a marginal difference between PD-L1 expression level of $\geq 5 \%$ and $<5 \%(\mathrm{P}=0.05)$ was shown in PFS analysis. Analysis by smoking history indicated favorable PFS and OS outcomes in former and current smokers, which could be explained by the expected higher mutational load in smoking-associated lung cancer. And there were separate anti-PD-1/PD-L1 therapy studies for squamous and non-squamous, this analysis indicated that anti-PD-1/PD-L1 therapy could provide similar benefit for squamous and non-squamous NSCLC.

Whether the benefit of anti-PD-1/PD-L1 therapy extends to patients with a tumour proportion score of less than $1 \%$ needs to be defined in future trials. KEYNOTE-024 trial [25] had indicated anti-PD-1/ PD-L1 therapy used as first-line therapy could improve treatment outcome than chemotherapy. Another ongoing study is also assessing anti-PD-1/PD-L1 therapy as firstline therapy (KEYNOTE-042, ClinicalTrials.gov number NCT02220894). This study is enrolling patients using distinct biomarker cutpoints, and the final analyses could provide help to determine which cutpoint best predicts activity of anti-PD-1/PD-L1 therapy monotherapy in these earlier lines of therapy. For those patients for whom anti-PD-1/PD-L1 therapy monotherapy is not as effective as cytotoxic chemotherapy, in combination with chemotherapy [26] or other immunotherapies [27] might be needed. Additional studies will also be needed to define the optimal duration of anti-PD-1/PD-L1 therapy.

Responses with anti-PD-1/PD-L1 therapy were seen in patients with EGFR- and KRAS-wildtype and EGFRand KRAS-mutant NSCLC; however, low numbers of enrolled patients in these trials precluded relationship of mutation status with clinical outcomes after anti-PD-1/PDL1 therapy. Futhermore, the introduction of anti-PD-1/PDL1 therapy and EGFR-TKIs for heavily pretreated patients with NSCLC had also created a dilemma regarding whether anti-PD-1/PD-L1 agent was better than EGFRTKIs, or vice versa. Using the common comparator of docetaxel, our indirect comparison indicated that PFS and OS with anti-PD-1/PD-L1 were superior to that with EGFR-TKIs. Meanwhile, for those EGFR mutant patients, anti-PD-1/PD-L1 therapy was inferior to EGFR-TKIs therapy in terms of PFS.

However, these findings should be viewed with caution: First caveat is that of relatively insufficient evidence because of the limitation of indirect comparison [23]. So, a direct head-to-head trial comparing anti-PD-1/ PD-L1 therapy versus EGFR-TKIs is clearly warranted

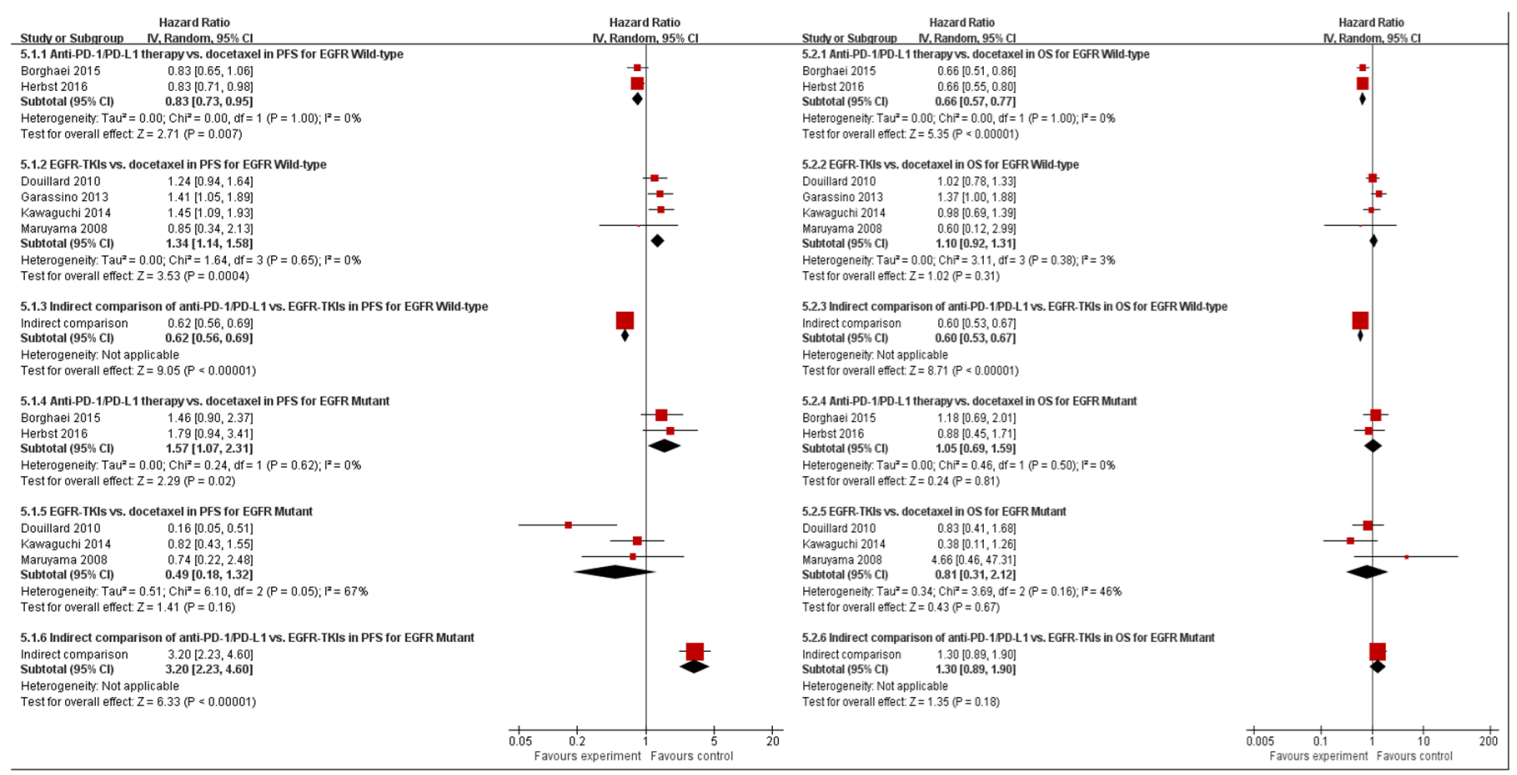

Figure 6: Indirect meta-analysis of treatment effects (anti-PD-1/PD-L1 therapy vs. EGFR-TKIs via common comparator) in progression free survival (PFS) (4.1.) and overall survival (OS) (4.2.) in previously heavily treated patients with and without EGFR mutation. CI: $95 \%$ confidence interval; Random: random-effects model. 
in future. Secondly, we used abstracted data, whereas an individual patient data-based analysis would provide a more precise estimate of the activity and safety of antiPD-1/PD-L1 therapy versus EGFR-TKIs. Thirdly, these studies were relatively heterogeneous with respect to patient population, disease status, and study design. For our primary outcomes analysis, the heterogeneity among selected studies were were low and non-significant for PFS $\left(\mathrm{P}=0.13, I^{2}=44 \%\right)$ and $\mathrm{OS}\left(\mathrm{P}=0.63, I^{2}=0 \%\right)$ analysis, high and significant for ORR ( $\left.\mathrm{P}<0.001, I^{2}=97 \%\right)$ analysis (Figure 2). Given this high and significant difference among these included trials for ORR analysis, the pooled ORR could be questioned.

In summary, anti-PD-1/PD-L1 therapy could produce clinical benefit over docetaxel for patients with previously treated NSCLC. For these EGFR wild-type patients, anti-PD-1/PD-L1 therapy seemed to prolong PFS and OS when compared with EGFR-TKIs. Meanwhile, among those EGFR mutant patients, anti-PD-1/PD-L1 therapy was inferior to EGFR-TKIs therapy in terms of PFS.

\section{MATERIALS AND METHODS}

\section{Literature search strategy}

The Cochrane Controlled Trial Register, Embase, Medline, and the Science Citation Index were searched using the medical subject headings "lung cancer", Atezolizumab", "Pembrolizumab", "Nivolumab", "Gefitinib" and "Erlotinib". Reference lists of selected reports were also hand-searched. This pooled analysis was approved by the institutional review boards of Weifang People's Hospital, in accordance with the Helsinki Declaration.

\section{Selection of studies}

Trials were included for this analysis if they met the following criteria: (1) They dealt only with previously treated advanced NSCLC patients. (2) They enrolled patients treated with anti-PD-1/PD-L1 therapy or EGFRTKIs.(3) Acceptable comparator was docetaxel. (4) They could provide data about adverse events rate, response rate, overall survival (OS) and (or) progression free survival (PFS). (5) These studies are prospective. Multiple reports about a single trial were considered as one. All potential trials were reviewed by two investigators separately (Y.X.Z and Z.X.S.).

\section{Quality assessment}

Two reviewers (Y.X.Z and Z.X.S.) independently assessed the quality of selected RCTs using the following criteria: (1) generation of allocation sequence, (2) description of dropouts, (3) masking of randomization, intervention, outcome assessment, (4) intention-to-treat analyses. Each criterion was rated as yes, no or unclear.

\section{Outcome measures}

The primary objective was to define the Hazard Ratios (HRs) of PFS and OS for anti-PD-1/PD-L1 therapy versus EGFR-TKIs, and calculate ORR from anti-PD-1/ PD-L1 therapy. The secondary objectives were to evaluate the Risk Ratio (RRs) of adverse events for anti-PD-1/PDL1 therapy versus docetaxel.

\section{Statistical analysis}

The indirect meta-analysis preserves the randomization within a RCT meanwhile, combines all available comparisons between treatments [23, 24]. These comparisons included both the direct within trial comparisons between two treatment strategies and the indirect comparisons constructed from trials that have one common comparator. When more than one RCT was available for comparison (e.g., anti-PD-1/PD-L1 therapy vs. Docetaxel), we first calculated the pooled estimates using standard meta-analytic techniques for that comparison. Using similar method, we obtained a pooled estimate from RCTs that compared other interventions (e.g., EGFR-TKIs vs. Docetaxel). Because both comparisons used docetacel as control, the summary estimates obtained from the respective meta-analysis (antiPD-1/PD-L1 therapy vs. Docetaxel and EGFR-TKIs vs. Docetaxel) can be used to provide estimates of the HR for the indirect comparison of anti-PD-1/PD-L1 therapy vs. EGFR-TKIs. The adjusted indirect comparisons were performed using the method described by Bucher et al [24]. According to this, an indirect comparison of interventions anti-PD-1/PD-L1 therapy vs. EGFR-TKIs can be obtained by adjusting the results of their direct comparisons with a common intervention of docetacel. If we assume that anti-PD-1/PD-L1 therapy ${ }_{\mathrm{MA}}$ is the estimate of direct comparison between intervention anti-PD-1/PDL1 therapy vs. docetacel and EGFR-TKIs ${ }_{\mathrm{MA}}$ is the direct comparison of intervention EGFR-TKIs vs. docetacel, then the estimate of the adjusted indirect comparison of intervention EGFR-TKIs vs. docetacel (such as log HR) is estimated by anti-PD-1/PD-L1 therapy ${ }_{\mathrm{MA}}$-EGFR-TKIs $_{\mathrm{MA}}$ $[23,24]$. Because the estimates are obtained from different studies, the results are statistically independent and its variance can be obtained by Var (log (anti-PD-1/PD-L1 therapy $\left._{\mathrm{MA}}\right)+\operatorname{Var}\left(\log \left(\mathrm{EGFR}^{-T_{K I s}}\right)\right.$ [23, 24].

All these analyses were undertaken using a randomeffects model which could provided a more conservative result. The heterogeneity among these trials was evaluated using Cochrane $\chi^{2}$ test and quantified with the $I^{2}$ statistic. Statistical heterogeneity was considered significant when the test produced a $\mathrm{P}$-value $<0.1$. The $I^{2}$ statistic was calculated as a measure of the degree of heterogeneity 
among selected studies, where $I^{2}$ values of $25 \%, 50 \%$ and $75 \%$ were considered low, moderate and high degrees of heterogeneity respectively. We also undertook subgroup analyses to sought the source of heterogeneity. Publication bias was evaluated with Egger's test. All meta-analyses were undertaken with Review Manager (version 5.3; The Cochrane Collaboration, Oxford, England) and Stata ver. 12.0 software (College Station, TX). Statistical significance was defined as a $\mathrm{P}$ value of less than 0.05 except for heterogeneity test.

\section{Abbreviations}

NSCLC: non-small-cell lung cancer; PD-1: programmed death 1; PD-L1: programmed death-ligand 1; PFS: progression free survival; OS: overall survival; EGFR-TKIs: epidermal growth factor receptor tyrosine kinase inhibitors; ORR: overall response rate; AEs: adverse events.

\section{Author contributions}

Yanxia Zhang participated in the design of the study and performed the statistical analysis. Zhixin Sheng performed the statistical analysis and drafted the manuscript. Xu Zhu and Yanhua Sun helped to perform the statistical analysis. All authors read and approved the final manuscript.

\section{ACKNOWLEDGMENTS}

We are indebted to Wenjun $\mathrm{Xu}$ for assistance with data analysis and critiquing the manuscript.

\section{CONFLICTS OF INTEREST}

The authors declare no competing financial interests.

\section{FUNDING}

The authors did not receive any financial support.

\section{REFERENCES}

1. Pardoll DM. The blockade of immune checkpoints in cancer immunotherapy. Nat Rev Cancer. 2012; 12:252-64.

2. Chen YB, MuCY, Huang JA. Clinical significance of programmed death-1 ligand-1 expression in patients with non-small cell lung cancer: a 5-year-follow-up study. Tumori. 2012; 98:751-5.

3. Velcheti V, Schalper KA, Carvajal DE, Anagnostou VK, Syrigos KN, Sznol M, Herbst RS, Gettinger SN, Chen L, Rimm DL. Programmed death ligand-1 expression in nonsmall cell lung cancer. Lab Invest. 2014; 94:107-16.

4. Brahmer JR, Drake CG, Wollner I, Powderly JD, Picus J, Sharfman WH, Stankevich E, Pons A, Salay TM,
McMiller TL, Gilson MM, Wang C, Selby M, et al. Phase I study of single-agent anti-programmed death-1 (MDX1106) in refractory solid tumors: safety, clinical activity, pharmacodynamics, and immunologic correlates. J Clin Oncol. 2010; 28:3167-75.

5. Fehrenbacher L, Spira A, Ballinger M, Kowanetz M, Vansteenkiste J, Mazieres J, Park K, Smith D, ArtalCortes A, Lewanski C, Braiteh F, Waterkamp D, He P, et al. Atezolizumab versus docetaxel for patients with previously treated non-small-cell lung cancer (POPLAR): a multicentre, open-label, phase 2 randomised controlled trial. Lancet. 2016; 387:1837-46.

6. Herbst RS, Baas P, Kim DW, Felip E, Pérez-Gracia JL, Han JY, Molina J, Kim JH, Arvis CD, Ahn MJ, Majem M, Fidler MJ, de Castro G Jr, et al. Pembrolizumab versus docetaxel for previously treated, PD-L1-positive, advanced non-small-cell lung cancer (KEYNOTE-010) a randomised controlled trial. Lancet. 2016; 387:1540-50.

7. Borghaei H, Paz-Ares L, Horn L, Spigel DR, Steins M, Ready NE, Chow LQ, Vokes EE, Felip E, Holgado E, Barlesi F, Kohlhäufl M, Arrieta $\mathrm{O}$, et al. Nivolumab versus docetaxel in advanced nonsquamous non-small-cell lung cancer. N Engl J Med. 2015; 373:1627-39.

8. Brahmer J, Reckamp KL, Baas P, Crinò L, Eberhardt WE, Poddubskaya E, Antonia S, Pluzanski A, Vokes EE, Holgado E, Waterhouse D, Ready N, Gainor J, et al. Nivolumab versus docetaxel in advanced squamous-cell non-small-cell lung cancer. N Engl J Med. 2015; 373:123-35.

9. Herbst RS, Soria JC, Kowanetz M, Fine GD, Hamid O, Gordon MS, Sosman JA, McDermott DF, Powderly JD, Gettinger SN, Kohrt HE, Horn L, Lawrence DP, et al. Predictive correlates of response to the anti-PD-L1 antibody MPDL3280A in cancer patients. Nature. 2014; 515:563-7.

10. Spigel DR, Chaft JE, Gettinger SN, Chao BH, Dirix LY, Schmid P, Chow LQ, Chappey C, Kowanetz M, Sandler A, Funke RP, Rizvi NA. Clinical activity and safety from a phase II study (FIR) of MPDL3280A (anti-PDL1) in PD-L1selected patients with non-small cell lung cancer (NSCLC). J Clin Oncol. 2015; 33:8028.

11. Horn L, Spigel DR, Gettinger SN, Antonia SJ, Gordon MS, Herbst RS, Sequist LV, Chappey C, Kowanetz M, Sandler A, Soria JC. Clinical activity, safety and predictive biomarkers of the engineered antibody MPDL3280A (antiPDL1) in non-small cell lung cancer (NSCLC): update from a phase Ia study. J Clin Oncol. 2015; 33:8029.

12. Garon EB, Rizvi NA, Hui R, Leighl N, Balmanoukian AS, Eder JP, Patnaik A, Aggarwal C, Gubens M, Horn L, Carcereny E, Ahn MJ, Felip E, et al. Pembrolizumab for the treatment of non-small-cell lung cancer. N Engl J Med. 2015; 372:2018-28.

13. Gandhi L, Balmanoukian A, Hui R, Hamid O, Rizvi NA, Leighl N, Gubens M, Goldman JW, Lubiniecki GM, Emancipator K, Dolled-Filhart M, Lunceford JK, Niewood M, et al. Abstract CT105: MK-3475 (anti-PD-1 monoclonal antibody) for non-small cell lung cancer 
(NSCLC): antitumor activity and association with tumor PD-L1 expression (KEYNOTE-025). Cancer Res. 2014; 74:CT105.

14. Gettinger SN, Horn L, Gandhi L, Spigel DR, Antonia SJ, Rizvi NA, Powderly JD, Heist RS, Carvajal RD, Jackman DM, Sequist LV, Smith DC, Leming P, et al. Overall survival and long-term safety of nivolumab (antiprogrammed death 1 antibody, BMS-936558, ONO-4538) in patients with previously treated advanced non-smallcell lung cancer. J Clin Oncol. 2015; 33:2004-12.

15. Rizvi NA, Mazières J, Planchard D, Stinchcombe TE, Dy GK, Antonia SJ, Horn L, Lena H, Minenza E, Mennecier B, Otterson GA, Campos LT, Gandara DR, et al. Activity and safety of nivolumab, an anti-PD-1 immune checkpoint inhibitor, for patients with advanced, refractory squamous non-small-cell lung cancer (CheckMate 063): a phase 2, single-arm trial. Lancet Oncol. 2015; 16:257-65.

16. Brahmer JR, Tykodi SS, Chow LQ, Hwu WJ, Topalian SL, Hwu P, Drake CG, Camacho LH, Kauh J, Odunsi K, Pitot HC, Hamid O, Bhatia S, et al. Safety and activity of antiPD-L1 antibody in patients with advanced cancer. N Engl J Med. 2012; 366:2455-65.

17. Topalian SL, Hodi FS, Brahmer JR, Gettinger SN, Smith DC, McDermott DF, Powderly JD, Carvajal RD, Sosman JA, Atkins MB, Leming PD, Spigel DR, Antonia SJ, et al. Safety, activity, and immune correlates of anti-PD-1 antibody in cancer. N Engl J Med. 2012; 366:2443-54.

18. Gettinger SN, Shepherd FA, Antonia SJ, Brahmer JR, Chow LQ, Juergens RA, Borghaei H, Shen Y, Harbison C, Alaparthy S, Chen AC, Rizv NA. First-line nivolumab (anti-PD-1; BMS-936558, ONO-4538) monotherapy in advanced NSCLC: safety, efficacy, and correlation of outcomes with PD-L1 status. J Clin Oncol. 2014; 32:8024.

19. Maruyama R, Nishiwaki Y, Tamura T, Yamamoto N, Tsuboi M, Nakagawa K, Shinkai T, Negoro S, Imamura F, Eguchi K, Takeda K, Inoue A, Tomii K, et al. Phase III study, V-15-32, of gefitinib versus docetaxel in previously treated Japanese patients with non-small-cell lung cancer. J Clin Oncol. 2008; 26:4244-52.

20. Douillard JY, Shepherd FA, Hirsh V, Mok T, Socinski MA, Gervais R, Liao ML, Bischoff H, Reck M, Sellers MV, Watkins CL, Speake G, Armour AA, et al. Molecular predictors of outcome with gefitinib and docetaxel in previously treated non-small-cell lung cancer: data from the randomized phase III INTEREST trial. J Clin Oncol. 2010; 28:744-52.

21. Garassino MC, Martelli O, Broggini M, Farina G, Veronese S, Rulli E, Bianchi F, Bettini A, Longo F, Moscetti L, Tomirotti M, Marabese M, Ganzinelli M, et al. Erlotinib versus docetaxel as second-line treatment of patients with advanced non-small-cell lung cancer and wild-type EGFR tumours (TAILOR): a randomised controlled trial. Lancet Oncol. 2013; 14:981-8.

22. Kawaguchi T, Ando M, Asami K, Okano Y, Fukuda M, Nakagawa H, Ibata H, Kozuki T, Endo T, Tamura A, Kamimura M, Sakamoto K, Yoshimi M, et al. Randomized phase III trial of erlotinib versus docetaxel as second- or third-line therapy in patients with advanced non-small-cell lung cancer: Docetaxel and Erlotinib Lung Cancer Trial (DELTA). J Clin Oncol. 2014; 32:1902-8.

23. Glenny AM, Altman DG, Song F, Sakarovitch C, Deeks JJ, D'Amico R, Bradburn M, Eastwood AJ. Indirect comparisons of competing interventions. Health Technol Assess. 2005; 9:1-134, iii-iv.

24. Bucher HC, Guyatt GH, Griffith LE, Walter SD. The results of direct and indirect treatment comparisons in metaanalysis of randomized controlled trials. J Clin Epidemiol. 1997; 50:683-91.

25. Reck M, Rodríguez-Abreu D, Robinson AG, Hui R, Csőszi T, Fülöp A, Gottfried M, Peled N, Tafreshi A, Cuffe S, O'Brien M, Rao S, Hotta K, et al. Pembrolizumab versus chemotherapy for PD-L1-positive non-small-cell lung cancer. N Engl J Med. 2016; 375:1823-33.

26. Papadimitrakopoulou V, Patnaik A, Borghaei H, Stevenson J, Gandhi L, Gubens MA, Yang JC, Sequist LV, Ge JY, Bourque J, Bachman RD, Im E, Gadgeel SM. Pembrolizumab (pembro; MK-3475) plus platinum doubletchemotherapy (PDC) as front-line therapy for advanced non-smallcell lung cancer (NSCLC): KEYNOTE-021 cohorts A and C. J Clin Oncol. 2015; 33:8031.

27. Patnaik A, Socinski MA, Gubens MA, Gandhi L, Stevenson J, Bachman RD, Bourque J, Ge JY, Im E, Gadgeel SM. Phase 1 study ofpembrolizumab (pembro; MK-3475) plus ipilimumab (IPI) assecond-line therapy for advanced nonsmall cell lung cancer (NSCLC): KEYNOTE-021 cohort D. J Clin Oncol. 2015; 33:8011. 